ity and direction of the General Assembly itself, at once gave the commission a standing with the General Assembly. The selection of the members of the commission from the bar, the probate courts, the trust institutions, and the general public made it a general and not a special-interest group. By asking all the active members of the bar to submit subjects for consideration, the commission had the benefit of a wide variety of suggestions from many angles. Above all, by taking plenty of time during the legislative off-year, the commission was able to do its work deliberately and unhurriedly and to give to each subject the consideration it merited.

While the commission expired by its own limitation with the I933 session of the General Assembly, the Governor requested the former members of the commission to consider and recommend to the r935 session any other needed legislation affecting estates and trusts and kindred subjects. This enables the commission in a way to carry on and round out its work of modernizing, simplifying, and codifying the law on these subjects.

The method of attacking the problem may not be feasible in just this way in some states. It has worked well in Delaware. It suggests to other states one way of going about the improvement of their fiduciary laws in a systematic and thoroughgoing way.

\title{
A PUBLICATION OF THE AMERICAN STATE STATUTE LAW*
}

Paul L. Sayre $†$

$7 \mathrm{HE}$ purpose $\mathrm{x}^{\mathrm{x}}$ of this paper is the preliminary and limited one of presenting the several plans for a publication of the American state statute law that have been evolved thus far, with some comment on their advantages and disadvantages and some explanation of the occasion for the undertaking itself and the service which we may reasonably expect it to render. Dean Wigmore and Professor Philbrick have been deeply interested in this matter for many years and have freely given of their time in canvassing the field. In here presenting several plans that have been evolved, and adding one of my own, I do not suggest for a moment

* A paper read before the joint table on Property and Legislation at the annual meeting of the Association of American Law Schools, December 27, 1934.

$\dagger$ Professor of Law, Iowa Law School.

I Professor Bordwell asked me to present "The Project For a Modern and Adequate Stimson," that is to say, a publication of the American statute law. This is an undertaking which he has urged for many years, in and out of season, and in the most courageous and generous spirit. His own monograph, The Statute Law of Wills, may well point the way to the larger work. 
that any one of these plans should be adopted. For one thing, they are presented only in outline form here, and one who approved any one of them in general would undoubtedly insist on many qualifications if it came to a question of immediate adoption.

The lawyer's contempt for statute law is proverbial. For instance, any law teacher is reasonably sure of a hearty laugh from his students if he relates the story of the young candidate for admission to the bar who told the examiners that he knew all the statute law in that state but could not pass the examination because the questions were based on the common law. The examiner answered, "Young man, you know the statute law, but that does not entitle you to be a lawyer. For all we can say, some fool legislators will come along tomorrow and repeal everything you know." To give another illustration, law teachers are rather inclined to cite the incident which has become a part of our teaching traditions, namely, that one at least of the chief causes for Langdell's resignation of the deanship at Harvard was the insistence of his faculty that the library invest a considerable sum of money in the state statutes.

This point of view is probably due in large part at least to the training which our lawyers, including our judges, have received. We are trained in case law. We regard statutes as purely mechanical appendages that any lawyer without previous training can handle according to his daily needs in the active practice. This is in part due no doubt to the paucity of statutes in the early middle ages and down, indeed, until the latter part of the industrial revolution. As Professor Plucknett has justly pointed out, ${ }^{2}$ however, we must remember that the distinction between statute law and case law in year books was much less marked than it is today. "Do not gloss the statute," said Chief Justice Hengham, in 1307,3 "for we know it better than you; we made it." On the purely factual side, however, we should remember also that while the total number of statutes was much less, the total number of decided cases was much lëss also. Finally, we must consider that the few statutes in the early law were indigenous to a period when most of law was relational and one's rights were fixed to an extraordinary degree by the many-sided and complicated relationships of feudalism. Today things are different on all three of these points: first, the legislative function of making the laws and the judicial function of construing them are, in theory at least, entirely distinct; second, while the number of statutes has greatly increased, the number of

${ }^{2}$ Theodore F. T. Plucknett, Statutes and Their Interpretation in the First Half of the Fourteenth Century (1922), I-6, 8-10.

3 Anon. Y.B. 33 and 35. Edw. I 82 (1307). 
decided cases has shown almost as great a relative increase; third, we have evolved many new relationships, due to the complicated industrial and social organization of the times, which could hardly be given effect as the relationships of feudalism went through the slow processes of judicial decision. Of course, over all these matters there is the greatly increased activity of the state itself, authority for which inevitably and traditionally lies in the statute rather than the judge-made law.

In spite of these difficulties and this traditional attitude, an excellent start was made by the late Frederick J. Stimson in his publication of American Statute Law in 1885 . This was a work involving expert judgment and scholarly effort in selecting that body of state statute law best adapted to collection and annotation, in the first place, and the actual arrangement and emphasis in the second place. In spite of its incidental errors, which are easy to point out now, so excellent is this work that it is still a book of constant reference, although it purported to be a medium of current information and is now out-dated some fifty years. For a distinguished treatise on some branch of the law, basic in character, to be so used in its original form after the passage of fifty years would be the highest praise; for this to be true of Professor Stimson's general compilation on current statute law is an extraordinary honor to him, though I fear also an extraordinary disparagement of the lawyers in this country since his time. To find an adequate reason for our failure to have further editions of this work or a new and more comprehensive work to take its place is impossible; to find even plausible explanations for our laxity and our fault is extremely difficult.

The work of the American Law Institute in its ambitious cffort to restate the common law is an undertaking of extraordinary magnitude. In this work the law teachers of the country took the leadership with the very generous cooperation of the bench and bar. When we look at it impersonally, we cannot but wonder that such an effort was ever made in the first place. Indeed, it is really incomprehensible to the English even today, as witness their confused efforts to comment on the several publications of the restatement. ${ }^{4}$ On the other hand, in view of the complication of state statute law, and the splendid work to deal with the difficulty which Mr. Stimson did fifty years ago, it seems even more difficult to understand that the legal profession in this country has not collected and annotated the basic fields of state statute law than that it has wisely and gallantly undertaken the restatement of the common law itself.

4 A Review of the Restatement of the Law of Contracts, by Sir Frederick Pollock, 47 Harv. L. Rev. $3^{63}$ (1933). For an excellent comment on this attitude of English lawyers, see Cecil A. Wright, Restatements of Contracts and Agency. I Univ. of Toronto L. J. 17 (1935). 
Perhaps part of the reason for this delay, or this failure, is due to aesthetics and human frailty. The sclection and annotation of statutcs is not attractive to most legal scholars. They regard it as a lowly task fit for the clerks in some publishing company perhaps, but not suitable to a man capable of original work in legal scholarship. It must be admitted that our traditional attitude toward statutes confirms this point of view. I think the great dependence of the profession on statute law today has significantly changed this traditional attitude, however, so that the difficulties of aesthetics are not fighting against the work of our best scholars in the field of statute law.

Wc still have a second difficulty. This is one we have come to discuss today. An adequate selection and annotation of a state statute law will not publish itself. We must first decide on some method to accomplish this task, in the importance of which we all agree.

Perhaps the chief methods suggested thus far are the following:

(x) that a separate institute be created, roughly similar to the American Law Institute, and that it perform this work of selection and annotation;

(2) that some law school which has an adequate library and has devoted its efforts significantly to legislation should undertake the work through a special institute or division within that law school;

(3) that some individual lawyer (preferably of superhuman scholarship, physical strength, and industry) should undertake the work and receive his remuneration, partly through the aid of some educational foundation, and partly through the commercial sales of the work itself.

The first proposal has the eminent analogy of the American Law Institute. The second proposal is supported by the splendid work done by the Harvard Law School in the ficld of international law, or Columbia University in the field of political science, and several other instances of a similar kind in other universities. The final proposal has the courageous example of Mr. Stimson himself in its support.

The second plan has the great advantage of utilizing a law school where there are books for the purpose, and where there are members of the faculty and students who can give a part of their time to this undertaking in such a way as to make it economical and efficient. I venture to suggest a fourth plan. Is not the task perhaps too great for any single law school at present, and, even if a single law school could do it, would it not be unwise to follow this course? Would it not be better to have the undertaking approved by resolution of the Association of American Law Schools, and carried out by some institute created independently, but acting through all of those law schools that are equipped to do the work and 
are willing to take part? One thinks at once that Harvard, Yale, Columbia, Northwestern, California, Duke, Chicago, and perhaps several other law schools, could assume at least a part of the burden now. Other law schools could be assigned an appropriate share of the work as their interest in the undertaking develops and their own equipment for doing the work becomes adequate. Such a plan would permit the utilization of the best men and the best equipment which the entire country affords. Unity, cohesion, and effective direction would be secured, however, through one independent institute, which would coordinate and direct all the work.

It would be most fortunate to receive some foundation support, since it seems unfair and perhaps impracticable for the several law schools to carry the whole load alone. I suggest, however, that a beginning can be made at once and that this association can make it. The American Law Institute itself took its rise from this association. This last year we created a special society for the study of American legal history. We could approve such a society or institute for statute law now, with a director who would work through reporters or other executive officers from the several law schools. These reporters could be assigned by the director appropriate divisions of statute law for work at their respective law schools with the aid of advisors and student assistants. It is altogether likely that this effort would not make much progress unless it got at least a temporary grant from some endowed foundation to care for the salary and incidental expenses of the director. Of coursc, there must be cooperation from those in active practice and from the judges. I do not regard this as a serious matter, however. Regardless of the way that practicing lawyers may talk and the judges may write, the entire profession is really conscious of its extraordinary ignorance of statute law and the immediate need of some alleviation. Surely no one can seriously doubt that the reasonable cooperation which is possible from bench and bar will be most generously forthcoming.

The importance of statute law is now recognized by the profession at large to a degree that would have been unthinkable even ten years ago. First, in the field of taxation and corporation law, some commercial publishers already publish the annotated statutes of the several states and Canada. The cost of this annotation, however, is so great that they are available only for a few law offices whose business justifies their purchase and a few of the better law libraries and financial libraries. Secondly, the American law Institute itself, especially in the field of property and 
criminal law, has used the statute law very widely and has recognized the power of statute law to vary our general legal concepts to a degree that few common law lawyers would have foreseen twenty years ago.

The need of an annotation of statute law for the several states is all the more urgent since we have no real integration of the statute law with the common law in any one state. On the continent, of course, their statute law represents the principal content of the legal order, and the case law is interpretive of the statutes. Even in England, they have, for instance, Halsbury's Laws of England, ${ }^{5}$ which is in the nature of an encyclopedia covering both case and statute law of England, and presenting the whole as one system, in which case law and statute law are almost completely merged. Indeed, American lawyers are often confused and even our better legal scholars are sometimes led into rather elementary errors because they fail to comprehend that the current presentation of the law in England is not sharply differentiated between case and statute law as it is with us. For instance an English text writer in commenting on the modern law of sales may well present the development in this field and give the present status of the law without indicating how much the present law turns on common law decisions in the old sense and how much it turns on the interpretation of various statutes. The particular statutes are mentioned very casually or perhaps omitted entirely, and the law is stated as a whole, without indicating its divisions into case-made and statute-made sources.

In view of our striking backwardness, compared with England, the great common law country, in integrating our statute law in our legal order, it is of the most importance for us at least to have our statute law in usable form. We will still be fifty years behind England, since we can hardly go far in integrating our statute law until we know what our statute law is.

Briefly then, the selection and annotation of state statute law at the present time is feasible; first, because in several of our law schools we already have the equipment for the work; second, because the commercial sale of this work would insure the undertaking considerable financial returns, due to the practical need for the statutes that lawyers at present experience; third, because the propaganda work and differences in scholarly opinion which have been so expensive and time-consuming for the American Law Institute in restating the common law would not be corresponding burdens in this more immediate and practical work of pre-

$s$ The Earl of Halsbury, The Laws of England (rgr3). 
senting the statute law of the several states for the first time in usable form; and fourth, because the honest use of our statute law for the daily needs of lawyers in the courts as well as the needs of law schools in all their work, and the development of the law itself, requires that we reach our maturity in understanding and using our legal system as a whole; this can never be done until we remove our own ignorance of our own statute law first. 